\title{
1 Toothless wildlife protection laws
}

2 José Vicente López-Bao ${ }^{1,2^{*}}$, Juan Carlos Blanco ${ }^{3}$, Alejandro Rodríguez ${ }^{4}$, Raquel

3 Godinho5,6, Víctor Sazatornil7 $^{7}$, Francisco Alvares ${ }^{5}$, Emilio J. García ${ }^{8}$, Luis Llaneza8,

4 Miguel Rico ${ }^{8}$, Yolanda Cortés ${ }^{3}$, Vicente Palacios ${ }^{8}$, Guillaume Chapron²

5

6

7

8

*E-mail: jv.lopezbao@gmail.com

${ }^{2}$ Grimsö Wildlife Research Station, Department of Ecology, Swedish University of Agricultural Sciences, 73091 Riddarhyttan, Sweden.

3Proyecto Lobo, CBC. C/ Manuela Malasaña 24, 28004 Madrid, Spain.

${ }^{4}$ Department of Conservation Biology, Estación Biológica de Doñana, CSIC, Américo Vespucio $s / n, 41092$ Sevilla, Spain.

${ }^{5}$ CIBIO/InBio - Centro de Investigação em Biodiversidade e Recursos Genéticos, Universidade do Porto, Campus Agrário de Vairão, 4485-661 Vairão, Portugal.

${ }^{6}$ Departamento de Biologia, Faculdade de Ciências, Universidade do Porto, 4169-007 Porto, Portugal

${ }^{7}$ Departamento de Biologia Animal, Facultad de Biologia, Universidad de Barcelona, 08028 Barcelona, Spain

${ }^{8}$ A.RE.NA. Asesores en Recursos Naturales, S.L. Perpetuo Socorro $n^{\circ}$ 12-Entresuelo, 2B, 27003, Lugo, Spain. 
Granting legal protection to an endangered species has long been considered a major milestone for its conservation and recovery. A multitude of examples such as wolves in the contiguous USA (Boitani 2003) or many large carnivore populations in Europe (Chapron et al. 2014) have revealed how instrumental wildlife protection laws can be for species recovery. However, legal obligations to conserve endangered species may be useless if the rule of law is not properly enforced. Such situation is not exclusive to countries with political instability or weak institutional capacities but can also be relevant, for instance, to member states of the European Union and therefore bound to European legislation on nature conservation.

The fate of the now critically endangered and isolated wolf (Canis lupus) population in Sierra Morena, southern Spain (Andalusia and Castilla-La Mancha Autonomous Regions), well illustrates this lack of compliance with law when preserving contentious species. In 1988, this population was estimated to number between 6 and 10 packs (Blanco et al. 1990). The population was granted both regional (Andalusia, Andalusian Regulation 4/86, January 22; Regional Government of Andalusia 1986; Castilla-La Mancha, Regulation 33/1998, May 5; Regional Government of Castilla-La Mancha 1998)and national protection in 1986 (Bern Convention; ratified by Spain in 1986; Spanish Official Bulletin 235, October 1, 1986, including the Iberian wolf in annex III: "protection of fauna species"; European Commission 1979), and later European protection under the Habitats Directive 92/43/EEC (annexes II and IV) in 1992. Despite this comprehensive and strict legal protection, the implementation of recovery actions by Andalusian authorities since 2003 (i.e. implementation of damage prevention measures and compensation systems; Andalusian Wolf Conservation Program; 
www.juntadeandalucia.es) and the approval by Spanish authorities in 2005 of a short-term recovery goal of 15 packs (Spanish Wolf Working Group 2005), all legally required conservation initiatives, have either failed or not been considered. For example, no population reinforcement has ever been implemented.

While no detailed information exists about the incidence of inbreeding (Ferrand et al. 2005) or infectious diseases on this population, multiple facts still suggest that, in the absence of efficient human persecution, population growth and recovery should have occurred. Wolves are known to exhibit a high biological resilience as illustrated by high growth rates even in very small and inbred populations (Vilà et al. 2003). When protection was granted, this population was large enough (6-10 packs; Blanco et al. 1990) to escape stochastic events and benefited from a good amount of wild prey and vegetation cover (Azorit et al. 1998; Blanco 2001). The population further occurs in an area with very few paved roads $\left(0.16 \mathrm{~km} / \mathrm{km}^{2}\right)$ and a remarkable low and decreasing human population (ca. 3 inhabitants $/ \mathrm{km}^{2}$ ) (Muñoz-Cobo et al. 2000; Blanco 2001; Muñoz-Cobo et al. 2002). Conflict with farmers has also remained at low intensity, with for example, a mean annual number of compensated livestock attacks attributed to wolves equal to 15.5 attacks between 1986 and 2012 in Andalusia (range 1-42; after a period of very low mean annual number of attacks between 1986 and $1994-2.8$ attacks-, this number increased to a mean of 25.8 attacks between 1995 and 2008, and dropped again to 1.8 attacks between 2009 and 2012; Andalusian Wolf Conservation Program; www.juntadeandalucia.es). Finally, Sierra Morena habitat could in fact be considered as more suitable than other areas with wolves in the Iberian Peninsula (Llaneza et al. 2012). 

even weaker legal status, where population stability or increase are the norm

90 (Chapron et al. 2014), this population has, after 28 years of protection, not recovered but instead declined with only 1 pack in 2012 (Kaczensky et al. 2013). It is worth mentioning that, in July 2014 in the region of Sierra Morena of Castilla-La Mancha, bordering with the Andalusian wolf range, twenty-five livestock breeders handling ca. 7,500 livestock heads (mainly sheep, 7,150 heads) in semi-extensive regimes reported not to have suffered any damage attributed to wolves nor having any evidence of wolf presence at least during the last decade (J.C. Blanco, com. pers.).

Unless effective actions are implemented, this population will be the first wolf population to become extinct in Europe in modern times. Despite wolf range here largely occurs in places legally listed as Sites of Community Importance within the Natura 2000 network (under the Habitats Directive) or even nature reserves, the main land use is large fenced private properties (covering $85 \%$ of the estimated wolf range in 2002; Muñoz-Cobo et al. 2002) running recreational big game hunting businesses through intensive game ranching (hunting business started in the 1970s and reached the dominance among land uses in less than 15 years). Game management causes red deer density to approach the highest figures in Europe (usually ranging between 20 and 60 heads $/ \mathrm{km}^{2}$, but up to ca. 100 heads $/ \mathrm{km}^{2}$; Azorit et al. 1998; Blanco 2001). The most traditional way of hunting here, namely montería, is based on the previous selection of dense vegetation patches where dogs are released to drive game ungulates to the surrounding open areas, where hunters are placed. In addition, apart from this commercial hunting, where hunters demand high hunting bags, other selective monterías are also 
113 carried out in order to increase trophy quality in the deer population of each 114 estate.

Such intense game management (e.g. game ungulates are provided with 116 food and water) facilitates predation on game ungulates by wolves, but also have triggered strong wolf persecution because of competition for game species and other economic loss associated to this hunting business (Blanco et al. 1990, 1992; Blanco 2001; Muñoz-Cobo et al. 2002). Predation impact of this small wolf population on the red deer population has been estimated to be negligible (between 0.3 and $0.7 \%$ of total deer biomass; Blanco et al. 1992). However, the renown of monterías depends on the number and quality of animals shot. The fact that wolves can displace game ungulates from the selected vegetation patches for the montería to other areas where hunting was not programmed impact on the profitability of the hunting. Although virtually no data have been collected on the 
wolves in Sierra Morena, proactive measures would include an intensive monitoring program using non-invasive DNA and animal collaring techniques to estimate the number of wolves remaining in this population, an effective strategy to detect and reduce the illegal killing of wolves (including educational programs or generating peer pressure for not poaching wolves) and, possibly, a population restocking. Such law enforcement may also require solving confronted sectoral and private interests.

\section{References}

Azorit C, Muñoz-Cobo J, Carrasco R (1998)Managing red deer populations in Sierra Morena, Jaén (South of Spain). In: Advances in Deer Biology: Proceedings of the IV International Deer Biology Congress, ed. Z. Zomborsky pp. 66-69. Kaposvár, Hungary.

Blanco JC, Rodríguez A, Cuesta L, Reig S, del Olmo JC (1990) El lobo en Sierra Morena. In: Blanco JC, Cuesta L, Reig S (eds) El lobo (Canis lupus) en España. Situación, problemática y apuntes sobre su ecología. Instituto para la Conservación de la Naturaleza, Madrid, Spain, pp. 61-68

Blanco JC, Reig S, Cuesta L (1992) Distribution, status and conservation problems of the wolf (Canis lupus) in Spain. Biol Cons 60:73-80.

Blanco JC (2001). El hábitat del lobo: la importancia de los aspectos ecológicos y socioeconómicos, In: Camprodon J, Plana E (eds) Conservación de la biodiversidad y gestión forestal. Su aplicación a la fauna vertebrada Universitat de Barcelona, Barcelona, Spain. pp. 415-432. 
Boitani L (2003) Wolf conservation and recovery. In: Mech D, BoitaniL (eds) Wolves, behavior, ecology and conservation. The University of Chicago Press, Chicago and London. pp. 317-340.

European Commission (1979) Convention on the conservation of European wildlife and natural habitats. Council of Europe, Bern.

Ferrand N, Godinho R, Lopes S, Carrasco R, Ortega F, Franco A, Blanco JC (2005) Análise genética preliminar do isolado populacional de lobo (Canis lupus) da Serra Morena (Andalucía, España): Aplicação de microssatélites, DNAmitocondrial e marcadores do cromossoma Y. II Congreso Luso-Español sobre el lobo ibérico. Castelo-Branco. Portugal.

Chapron G, et al. (2014) Recovery of large carnivores in Europe's modern humandominated landscapes. Science 346:1517-1519.

Llaneza L, López-Bao JV, Sazatornil V (2012) Insights into wolf presence in human-dominated landscapes: the relative role of food availability, humans and landscape attributes. Divers Dist 18:459-469.

Kaczensky P, Chapron G, von Arx M, Huber D, Andrén H, Linnell J (2013) Status, management and distribution of large carnivores - bear, lynx, wolf and wolverine - in Europe. Report to the EU Commission, 272 p.

Muñoz-Cobo J, Azorit C, Calvo JA, Carrasco R (2000)El lobo en Sierra Morena: Estado actual, amenazas y medidas de conservación. Serie Zoológica. Universidad de Navarra 26: 101-127.

Muñoz-Cobo J, Azorit C, Calvo JA, Carrasco R (2002) Pasado y presente del lobo en Sierra Morena. Aportaciones a la gestión sostenible de la caza. FEDENCA-ECC, 275-293. 
194

Spanish Wolf Working Group (2005) Strategy for the conservation and management of the wolf (Canis lupus) in Spain (Environmental Sector Conference, Madrid, 2005 , www.magrama.gob.es/es/biodiversidad/temas/conservacion-de-especiesamenazadas/LOBO tcm7-164142.pdf).

Vilà C, Sundqvist AK, Flagstad Ø, Seddon J, Kojola I, Casulli A, Sand H, Wabakken P, Ellegren H (2003) Rescue of a severely bottlenecked wolf (Canis lupus) population by a single immigrant. Proc R Soc B 270:91-99.

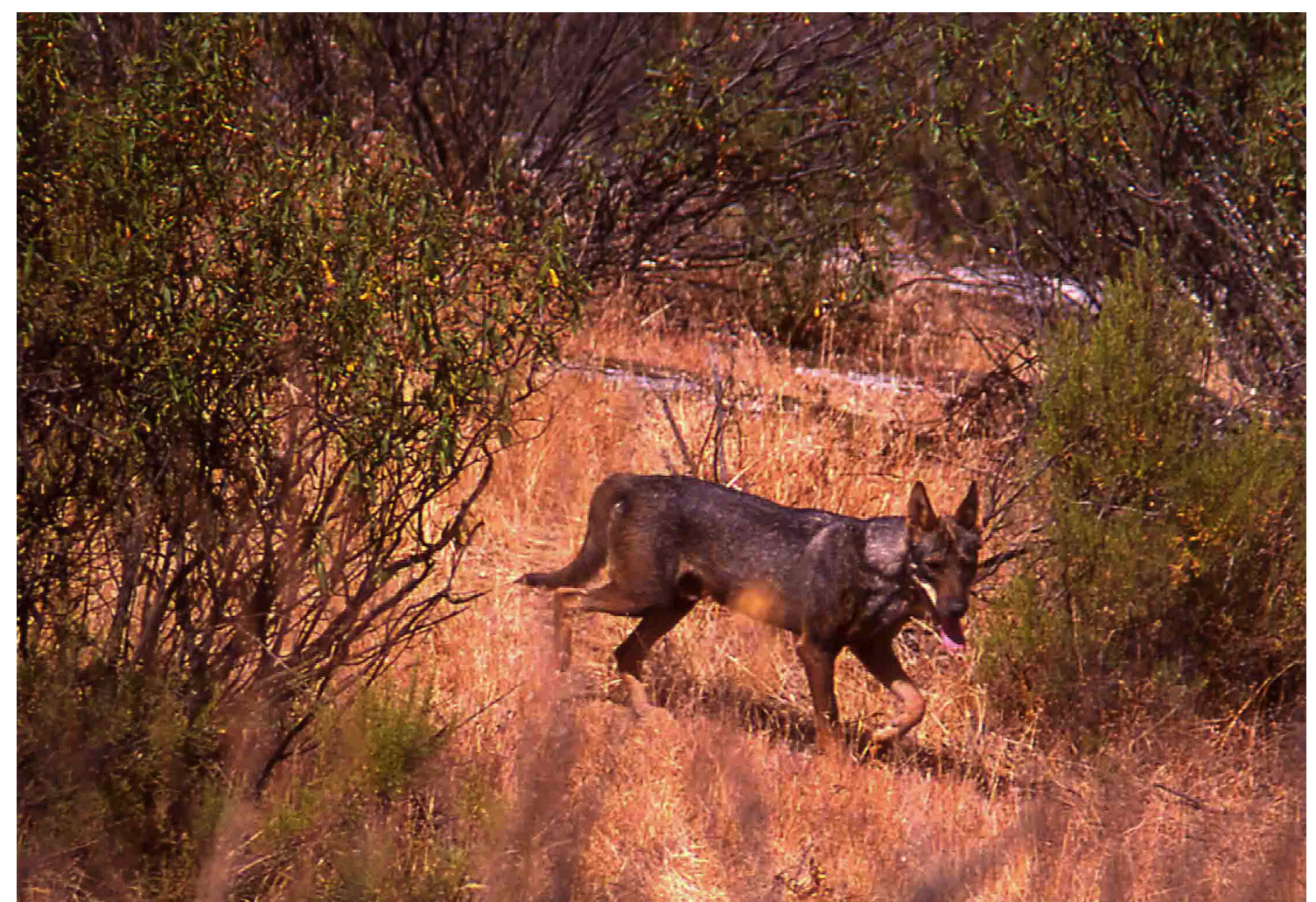

One of the last graphic evidence of wolves in Sierra Morena from 2006. Photo courtesy of Francisco José García. 